\title{
ERRATUM
}

E. M. Gorostiaga · M. Izquierdo · M. Ruesta

J. Iribarren · J. J. González-Badillo · J. Ibáñez

\section{Strength training effects on physical performance and serum hormones in young soccer players}

Published online: 17 November 2004

(C) Springer-Verlag 2004

\section{Eur J Appl Physiol (2003) 91:698-707}

In Figure 4, the axes were not correctly aligned. The correct version is given below.

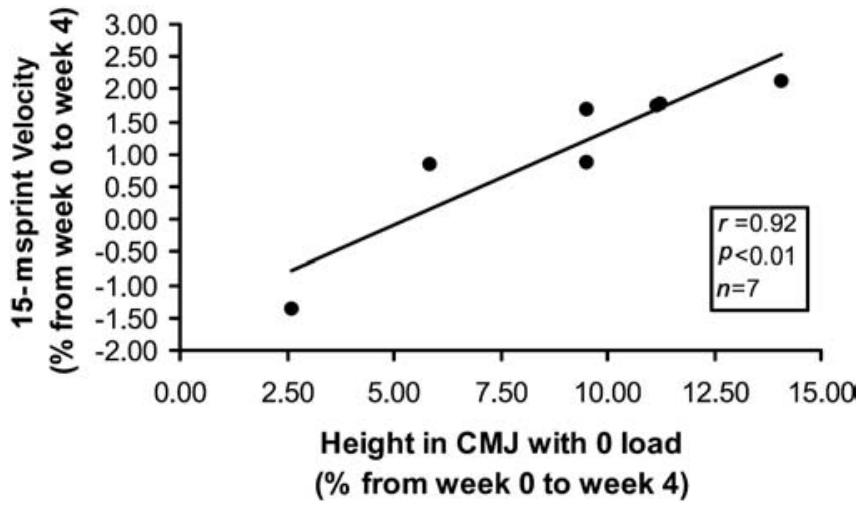

Fig. 4 Relationships between the individual percentage changes in CMJ0 and the individual percentage changes in $15-\mathrm{m}$ average running velocity during the first 4 weeks of the 11-week training period in the $\mathrm{S}$ group ( $n$ number of subjects)

The online version of the original article can be found at http:// dx.doi.org/10.1007/s00421-003-1032-y

E. M. Gorostiaga $(\bowtie) \cdot M$. Izquierdo $\cdot$ M. Ruesta $\cdot$ J. Ibáñez Centro de Investigación y Medicina del Deporte de Navarra, Gobierno de Navarra, C/ Paulino Caballero 13,

31002 Pamplona, Spain

E-mail: egorosta@cfnavarra.es

Tel.: + 34-948-292622

Fax: $+34-848-427835$

J. Iribarren

Club Atlético Osasuna, Pamplona, Spain

J. J. González-Badillo

Centro Olímpico de Estudios Superiores,

Comité Olímpico Español, Madrid, Spain 